\title{
The Rupelian-Chattian boundary in the North Sea Basin and its calibration to the international time-scale
}

\author{
S. Van Simaeys \\ Historical Geology, University of Leuven, Redingenstraat 16, B-3000 Leuven, Belgium. \\ Fax: +32-16-32-64-01. E-mail: stefaan.vansimaeys@geo.kuleuven.ac.be
}

Manuscript received: February 2004; accepted: August 2004

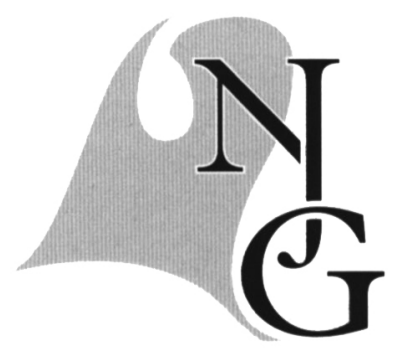

\begin{abstract}
The classical problem of the nature and age of the Rupelian-Chattian (Early-Late Oligocene) unconformity in its type region is here approached using organic walled dinoflagellate cyst (dinocyst) correlations between the North Sea Basin and wellcalibrated central Italian (Tethyan Ocean) sections. Useful Oligocene dinocyst events are the last occurrence of Enneadocysta pectiniformis $(\sim 29.3 \mathrm{Ma})$, and the first occurrences of Saturnodinium pansum $(\sim 29.4 \mathrm{Ma})$, Distatodinium biffii $(\sim 27.9 \mathrm{Ma})$ and Artemisiocysta cladodichotoma $(\sim 26.7 \mathrm{Ma})$. The latter event marks the earliest Chattian. The improved correlations indicate that the Rupelian-Chattian (R-C) boundary is associated with the so-called 'Oligocene Glacial Maximum'. This phase of important global cooling and glacio-eustatic sea level fall is genetically related to the unconformity between the classic Oligocene stages. Subsequent global warming (so-called 'Late Oligocene Warming Event'), induced a major sea level rise, leading e.g. to the time-transgressive deposition of the typical basal Chattian glauconitic sands. The oldest of the Chattian units have a GPTS age of $\sim 26.7 \mathrm{Ma}$. It further appears that a hiatus of $\sim 500$ kyrs spans the classic Rupelian-Chattian unconformity.
\end{abstract}

Keywords: biochronostratigraphy, dinoflagellate cysts, North Sea Basin, Rupelian-Chattian boundary, Tethyan Ocean

\section{Introduction}

The Oligocene successions of the southern North Sea Basin (Fig. 1) are internationally important in that they constitute the classic Rupelian (Lower Oligocene) and Chattian (Upper Oligocene) stratotype sections. Currently, efforts are underway to establish a Global Boundary Stratotype Section and Point (GSSP) for the R-C boundary on the basis of continuous central Italian sections (Coccioni et al., submitted). According to the concepts of the International Stratigraphic Guide (Salvador, 1994), definition of a chronostratigraphic unit should place emphasis on the selection of the boundary stratotype of its lower boundary; its upper boundary is than defined as the lower boundary of the overlying unit. This concept implies that any
R-C GSSP ideally should coincide with the base of the classic Chattian Stage, stressing the importance of its characterisation.

The lowermost layers of the Chattian unit-stratotype, i.e. the Doberg section in NW Germany, are long since known as the 'Asterigerina Horizon', named after the bloom of the benthic foraminifer Asterigerinoides guerichi. This distinct and widespread bloom can be recognised throughout the North Sea Basin (e.g. Ellermann, 1958; Indans, 1958, 1965; Doppert \& Neele, 1983; Ulleberg, 1987; King, 1983, 1989; see overview in Van Simaeys et al., 2004) and thus allows clear recognition of the R-C boundary in its type region (Van Simaeys et al., 2004). However, accurate calibration of this bioevent to the international polarity time-scale (GPTS) has been notoriously hampered 


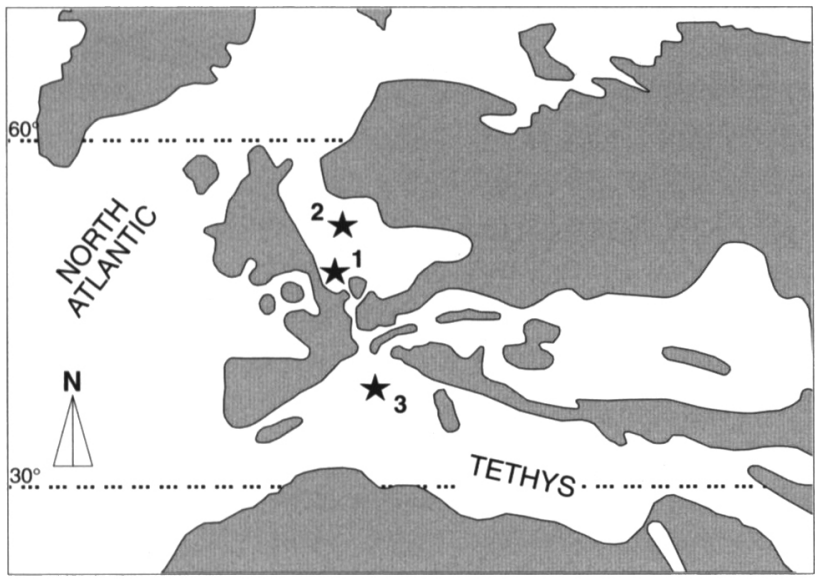

Fig. 1. Paleogeographic reconstruction of the European continent during mid Oligocene times, with the locations of the 1 . southern and 2. central North Sea Basin successions and 3. central Italian sections (modified from Ziegler, 1990; Scotese \& Golanka, 1992 and Sissingh, 2003).

by 1 . the endemic nature of the North Sea Oligocene benthic foraminifera, 2 . the sparcity of chronostratigraphic important calcareous plankton in the Rupelian and Chattian marginal-marine type and reference sections and 3. limited availability of reliable paleomagnetic signals and/or absence of radiometric datable layers in both stratotype sections and regions.

The current biochronological concept of the R-C boundary is based on the last occurrence datum (LOD) of (common) chiloguembelinids (planktonic foraminifera), formalised as the $\mathrm{P} 21 \mathrm{a} / \mathrm{b}$ subzonal boundary, calibrated against (mid) magnetopolarity subchron C10n, with an estimated GPTS age of $\sim 28.5 \mathrm{Ma}$ (e.g., Berggren et al., 1995). However, application of this concept - the LOD of the chiloguembelinids - is problematic (Van Simaeys et al., 2004). It has become clear that the extinction of chiloguembelinids is not isochronous on a global scale, but is most likely controlled by paleolatitude and paleobiogeography (Van Simaeys et al., 2004). The timetransgressive extinction of chiloguembelinids, first at high latitudes and later at low latitudes, reflects regional extinction due to gradual, pervasive cooling of the surface waters during this time. Moreover, in the southern North Sea Basin, including the classic stratotypes, chiloguembelinids are only recorded as isolated occurrences in the lower Rupelian sections (see for further discussion Van Simaeys et al., 2004; De Man et al., 2004).

Outside the North Sea Basin only few well-calibrated, accessible, and continuous Oligocene successions have been documented. The most important among these are the relatively undisturbed, well-exposed pelagic sections in Italy (Fig. 1), which have come to play a principal role in the quest for Paleogene GSSPs. The
Massignano section (central Italy) has been ratified as the GSSP for the base of the Oligocene (Odin \& Montanari, 1988, 1989), and the Lemme section (NW Italy) for the base of the Miocene (Steininger et al., 1997). Various central Italian sections (e.g., Contessa Quarry, Monte Cagnero and Pieve d'Accinelli section) are now being evaluated as candidates for the basal Chattian GSSP (Coccioni et al., submitted). Much recent effort has been devoted to the establishment of an integrated biochronostratigraphic frame for these mid Oligocene sections, with detailed organic walled and calcareous plankton zonations and accurate radiometric age-assessments (Coccioni et al., submitted). As explained above, in order to define a R-C GSSP in the pelagic central Italian successions, it is of principal importance to understand their relationship with the classic marginalmarine unit-stratotypes of Rupelian and Chattian stages in the North Sea Basin (e.g. the discussion concerning the positioning of the Eocene-Oligocene boundary in Brinkhuis \& Visscher, 1995). For the R-C boundary, this is especially challenging, as most of the biotic events used in standard Oligocene zonation schemes are not recorded in the North Sea Basin because of its generally restricted- to shallow marine setting during this time.

Organic walled dinoflagellate cysts (dinocysts) have been demonstrated to have good potential for establishing correlations between deep and marginal marine successions from widely different depositional environments (e.g., Brinkhuis \& Visscher, 1995). Wellcalibrated, high-resolution dinocyst zonal schemes covering the entire Oligocene have been established on the basis of central Mediterranean deep and shallow marine successions (e.g., Brinkhuis et al., 1992; Brinkhuis \& Biffi, 1993; Brinkhuis 1994; Zevenboom, 1995; Wilpshaar et al., 1996). Recently, dinocyst associations from the mid Oligocene central Italian sections (Contessa Quarry, Monte Cagnero and Pieve d'Accinelli section) were (re)investigated in higher detail and resolution in the frame of follow-up projects aimed at obtaining more accurate chronostratigraphic and absolute age calibrations (Coccioni et al., submitted; Van Simaeys et al., in prep.). In addition, recent dinocyst studies from several boreholes in the southern North Sea Basin revealed that well preserved and diverse dinocyst associations occur throughout most of the upper Rupelian and lower Chattian sections (Van Simaeys et al., 2004). The latter resulted in the establishment of a new, high resolution Oligocene dinocyst zonation scheme for the southern North Sea Basin (Van Simaeys et al., in press).

The principal objectives of the present study are to 1. attempt correlation of dinocyst events from the upper 
Rupelian and lower Chattian unit-stratotypes from the southern North Sea Basin with their well-calibrated counterparts from central Italy, 2. determine the nature and age of the R-C unconformity, and 3. elaborate on the paleoenvironmental changes associated with this transition.

\section{Mid Oligocene dinocyst events}

\section{The southern North Sea Basin}

In the southern North Sea Basin, the dark green, glauconite-rich, fine Chattian sands, unconformably overlie the upper Rupelian silty clays (e.g., Vandenberghe et al., 1998, 2001). An integrated study on various groups of microfossils showed that the R-C unconformity is associated with a hiatus, marking a major change in paleotemperature and paleobathymetry. Shallow marine to restricted marine subtropical species at the base of the Chattian strongly contrast with the deeper marine and cool-temperate upper Rupelian biota (Van Simaeys et al., 2004; De Man \& Van Simaeys, 2004). These records are indicative of a sea level driven unconformity and hiatus between the top of the Rupelian and the base of the Chattian transgression (Van Simaeys et al., 2004).
The recently established Oligocene dinocyst zonation for the southern North Sea Basin (Van Simaeys et al., in press) is applicable to both the marginalmarine Oligocene sections from onshore NW Europe and the sparse Oligocene dinocyst data from the central North Sea Basin (Fig. 1). Several dinocyst events occur near the R-C transition and are calibrated against other microfossil zones for the southern North Sea Basin and to the paleotemperature curve based on benthic foraminiferal assemblages (De Man \& Van Simaeys, 2004; see Fig. 2). Useful dinocyst events in the upper Rupelian and lower Chattian are the last occurrence (LO) of Enneadocysta pectiniformis, which virtually coincides with the first occurrence (FO) of Saturnodinium pansum; these dinocyst events define the base of the NSO-4b zone (Van Simaeys et al., in press). The FO of Distatodinium biffii defines the base of NSO-5a; this event occurs in the upper part of the Rupelian, well below the base of the Chattian, the latter as recognised by the bloom of benthic foraminifer Asterigerinoides guerichi. The FO of Artemisiocysta cladodichotoma is at the base of NSO$5 \mathrm{~b}$, and coincides with the onset of the 'Asterigerina Horizon'. The LO of Rhombodinium draco is a little younger than the base of the Chattian. Higher up the Late Oligocene, the last occurrence of Areoligera

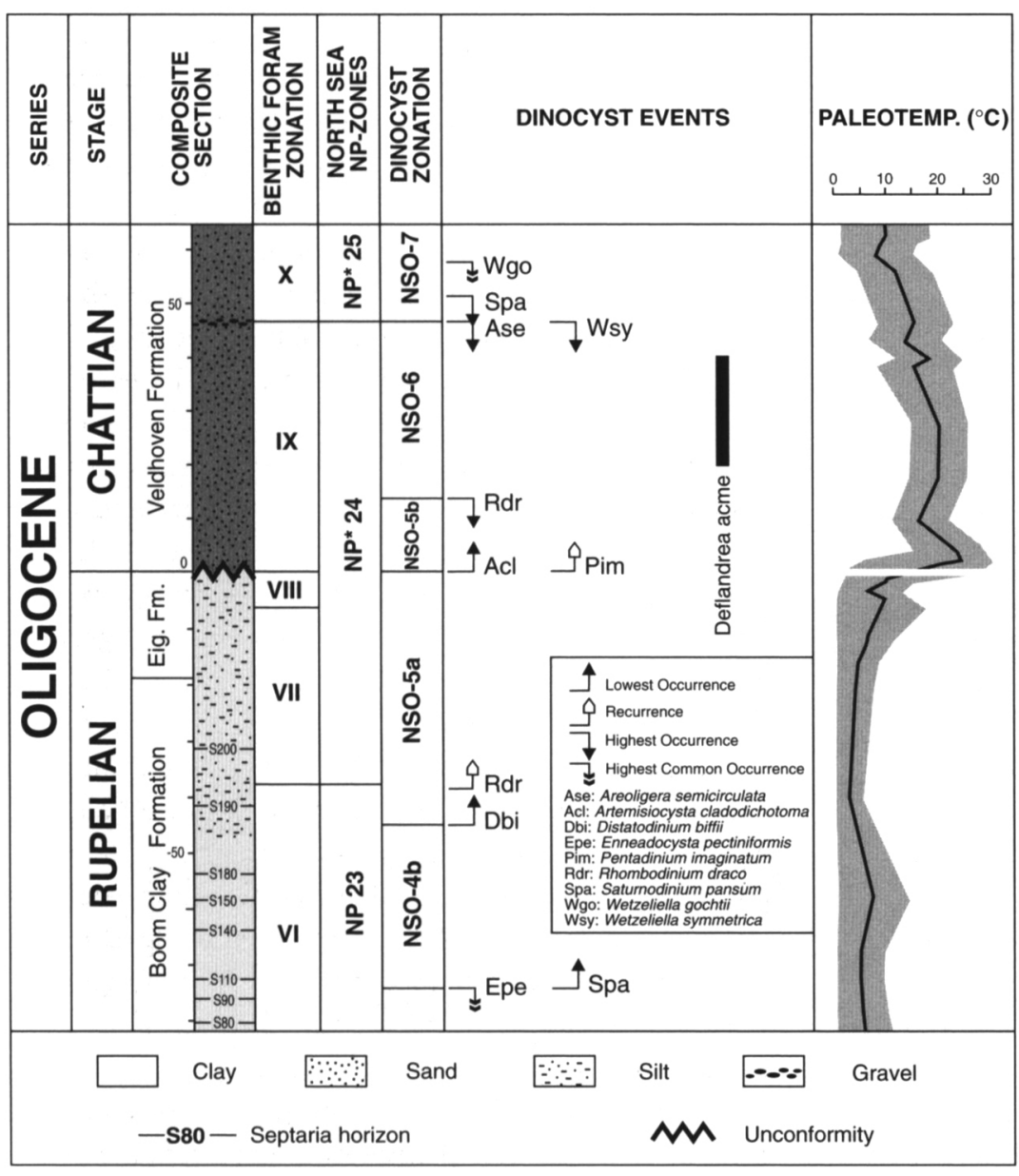

Fig. 2. Composite diagram of the mid Oligocene dinoflagellate cyst events in the southern North Sea Basin (after Van Simaeys et al., in press), correlated against the southern North Sea Basin benthic foraminiferal zonation scheme (after De Man et al., 2004), the North Sea nannoplankton zones (after Van Simaeys et al., 2004) and the paleotemperature curve as constructed by De Man \& Van Simaeys (2004). (Eig. Fm. = Eigenbilzen Formation). 
semicirculata and Saturnodinium pansum define the top of the NSO-6 zone (Van Simaeys et al., in press; see Fig. 2).

\section{The central.Mediterranean region}

To establish a detailed Oligocene dinocyst zonation. for the Mediterranean area, a number of otherwise well documented central Italian sections have been investigated. High-resolution dinocyst zonations have been established for the lower (Brinkhuis \& Biffi, 1993), mid (Wilpshaar et al., 1996) and upper (Zevenboom et al., 1995) Oligocene pelagic sections and are calibrated against the planktonic foraminifera and calcareous nannoplankton zonations as well as to the global polarity time scale (GPTS). In the light of new and more accurate age assessments (Coccioni et al., submitted), the dinocysts from three pelagic central Italian sections, respectively the Monte Cagnero, Pieve d'Accinelli and Contessa section were reinvestigated (Coccioni et al., submitted; Van Simaeys et al., in prep.). These studies led to a re-evaluation of the former proposed mid Oligocene dinocyst zones, calibrated against updated magnetobiostratigraphic information. The FO of Distatodinium biffii, defining the base of the Distatodinium biffii (Dbi) Interval Zone (Wilpshaar et al., 1996), is now correlated to the uppermost part of magnetochron $\mathrm{C} 9 \mathrm{r}$ and, assuming constant sediment accumulation rates, has an estimated age of $27.9 \mathrm{Ma}$ (Van Simaeys et al., in prep.).
Isolated records of Artemisiocysta cladodichotoma are recorded from the uppermost part of magnetochron $\mathrm{C} 9 \mathrm{n}$ and the lower part of C8r, at a level near two volcanic ash layers, dated respectively at $27.1 \mathrm{Ma}$ for the lower and 26.7 Ma for the upper (Coccioni et al., submitted; see Fig. 3). A remarkable dinocyst event from the central Mediterranean successions is recorded in the interval between the FO of Distatodinium biffii and the FO of Artemisiocysta cladodichotoma: representatives of the Arctic genus Svalbardella are conspicuously present (up to $10 \%$ ) in a distinct interval correlative to the upper part of subchron C9n. The Svalbardella interval terminates before the onset of subchron C8r. The estimated duration for the Svalbardella interval, based on radiometric and magnetostratigraphic age assessments, and assuming constant sedimentation rates, is $\sim 500$ kyrs (Van Simaeys et al., submitted; see Fig. 3 and discussion below).

\section{Calibration of the mid Oligocene dinocyst events in the southern North Sea Basin}

Despite the increasing amount of first-order correlations between dinocyst events and the GPTS (Brinkhuis et al., 2003; Williams et al., 2004; Eldrett et al., 2004), still only few well calibrated mid Oligocene dinocyst studies are available. Despite these restrictions, some North Sea events show good potential for interregional correlation and calibration. According to Williams et al. (2004), the FO of Saturnodinium

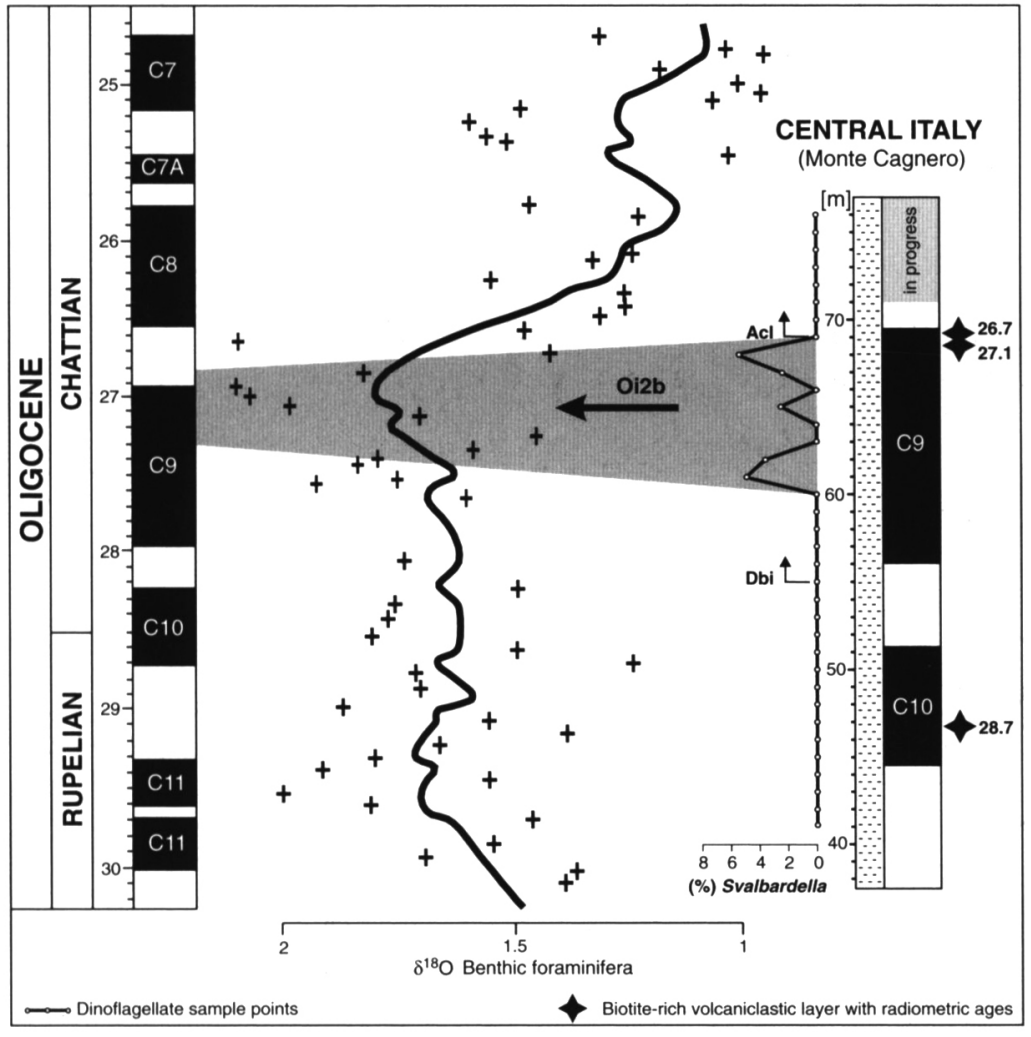

Fig. 3. Oligocene deep-sea benthic foraminiferal $\delta^{18} \mathrm{O}$ curve (after Miller et al., 1998), calibrated against the Monte Cagnero section in central Italy (magnetostratigraphy and radiometric age assessment after Coccioni et al., submitted; dinoflagellate cyst events after Van Simaeys et al., in prep.). The grey zone indicates the Svalbardella abundance in the upper part of magnetochron $\mathrm{C} 9 \mathrm{n}$ and is termed as the Oligocene Glacial Maximum (OGM). (Same abbreviations as in Fig. 2). Rupelian-Chattian boundary according to the concepts of the magnetobiochronologic time-scale (Berggren et al., 1995). 
pansum and the LO of Enneadocysta pectiniformis in Northern Hemisphere mid latitudes occur respectively at 29.4 and $29.3 \mathrm{Ma}$. Hence, we here attribute an age of $\sim 29.4 \mathrm{Ma}$ for the base of NSO-4b (Fig. 4). Assuming an isochronous first occurrence for Distatodinium biffii and Artemisiocysta cladodichotoma in both the North Sea Basin and Tethyan Ocean, and considering the first occurrence of these species in the well-calibrated central Italian sections, the agecalibration for the base of NSO-5a and NSO-5b is respectively $\sim 27.9$ and $\sim 26.7 \mathrm{Ma}$ (Fig. 4).

\section{The Oligocene Glacial Maximum, the Late Oligocene Warming Event and the Rupelian- Chattian unconformity}

A globally synchronous Svalbardella abundance has been recorded in the middle to upper part of magnetochron C9n (Van Simaeys et al., submitted; see Fig. 3 and Fig. 4). The abundance of this Arctic, cold water taxon, in both high and low latitudes, pointing to a lowering of the sea surface temperature (SST), is consistent with the reported timing of one of the major Oligocene deep-sea benthic foraminiferal $\delta^{18} \mathrm{O}$ events, known as the Oi2b-event (Miller et al., 1991, 1998; see Fig. 3), and hence favours a scenario of global cooling and concomitant Antarctic ice-sheet expansion (Van Simaeys et al., submitted). This episode, representing $\sim 500$ kyrs of profound global cooling, is termed 'Oligocene Glacial Maximum' (OGM), and has a calculated age of $\sim 27.3$ to $\sim 26.8 \mathrm{Ma}$ (see Fig. 3). These ages are based on accurate ${ }^{40} \mathrm{Ar} /{ }^{39} \mathrm{Ar}$ datings of biotiterich volcaniclastic layers at the very top of chron $\mathrm{C} 9 \mathrm{n}$ in central Italy (Coccioni et al., submitted). In Van Simaeys et al., submitted, the OGM has a GPTS age of 27.5 to 27.0 Ma after Berggren et al., 1995 .

So far, no distinct Svalbardella abundance has been recorded in the upper Rupelian and lower Chattian successions from the southern North Sea Basin (see Fig. 2 and Fig. 4). This Arctic, cold water taxon, if found at all, has only been picked up as isolated, reworked specimens in basal Chattian successions (Van Simaeys et al., 2004). Recently, however, sidewall samples from a thick $(>1000 \mathrm{~m})$ Oligocene section in the central North Sea Basin, i.e. the Mona-1 borehole, revealed a distinct Svalbardella abundance (up to 6\%) in a sample above the FO of Distatodinium biffii and below the FO of Artemisiocysta cladodichotoma (Van Simaeys, personal observations; HeilmannClausen, pers. com.; see Fig. 4). This record demonstrates that the Svalbardella event also occurred in the North Sea Basin, at the same chronostratigraphic position as compared to the central Mediterranean records (Fig. 4). As mentioned above, a distinct sea level driven unconformity is universally present in southern North Sea Basin successions in the interval between the FO of Distatodinium biffii and the FO of Artemisiocysta cladodichotoma, marking the R-C boundary. Only in more offshore settings (i.e. central North Sea) the correlative conformity, representing the lowstand and early transgressive phase, has been preserved; these units being marked by the Svalbardella abundance.

Combined evidence thus strongly suggests that all these phenomena are tied to the OGM. It suggests a scenario of global cooling, concomitant Antarctic icesheet growth and significant glacio-eustatic sea level fall. The global sea level low caused sub-aerial exposure and erosion of the marginal to restricted marine settings. This lowstand phase resulted in a major break in sedimentation. The subsequent transgression is here related to the warming during magnetochron C8, known as the 'Late Oligocene Warming Event' (LOWE, Zachos et al., 2001). This phase induced the basal Chattian major sea level rise, depositing tropical to subtropical time-transgressive sediments (see De Man \& Van Simaeys, 2004), unconformably overlying older strata. The preceding colder (OGM) phase is witnessed by isolated, reworked specimens of Svalbardella spp. at the base of the Chattian in the southern North Sea Basin (Van Simaeys et al., 2004).

Attributing the OGM, and the corresponding glacio-eustatic sea level fall, to the R-C unconformity in the southern North Sea Basin, has considerable implications for the age assessment of the R-C boundary: Since the OGM correlates to the upper part of magnetochron $\mathrm{C} 9 \mathrm{n}$, with a derived radiometric and GPTS age of $\sim 27.3$ to $\sim 26.8 \mathrm{Ma}$, the base of the Chattian unit-stratotype is not older then $\sim 26.8$ Ma. The subsequent Late Oligocene Warming Event, calibrated against magnetochron $\mathrm{C} 8$, reaches the lowest deep-sea benthic foraminiferal $\delta^{18} \mathrm{O}$ values around $\sim 26 \mathrm{Ma}$ (Miller et al., 1998; Zachos et al., 2001). If one assumes that age for the LOWE sea level maximum, the third order sea level fluctuation spanned some $\sim 0.8 \mathrm{Ma}$. This also indicates that the oldest of the time-transgressive glauconitic fine Chattian sands in the southern North Sea Basin, were deposited close to $26.7 \mathrm{my}$ ago. The R-C hiatus (unconformity) thus spans some $500 \mathrm{kyrs}$ (i.e. from $\sim 27.3$ to $\sim 26.8 \mathrm{Ma}$ ). This assessment matches the dinocyst-based (GPTS) ages for the top of the Rupelian and the base of the Chattian.

\section{Concluding remarks}

Dinocyst biostratigraphy enables correlation between the mid Oligocene North Sea Basin successions and 
the well-calibrated pelagic sections from central Italy. Based on the established correlations, and assuming isochronous first occurrences, the lower boundaries of the North Sea Oligocene dinocyst zones NSO-5a (top Rupelian) and NSO-5b (base Chattian) are respectively dated as 27.9 and $26.7 \mathrm{Ma}$. In all probability, the recorded Svalbardella abundance in the central North Sea Basin occurred at the same chronostratigraphic position as compared to the central Mediterranean records, and is attributed to the Oligocene Glacial Maximum (OGM).
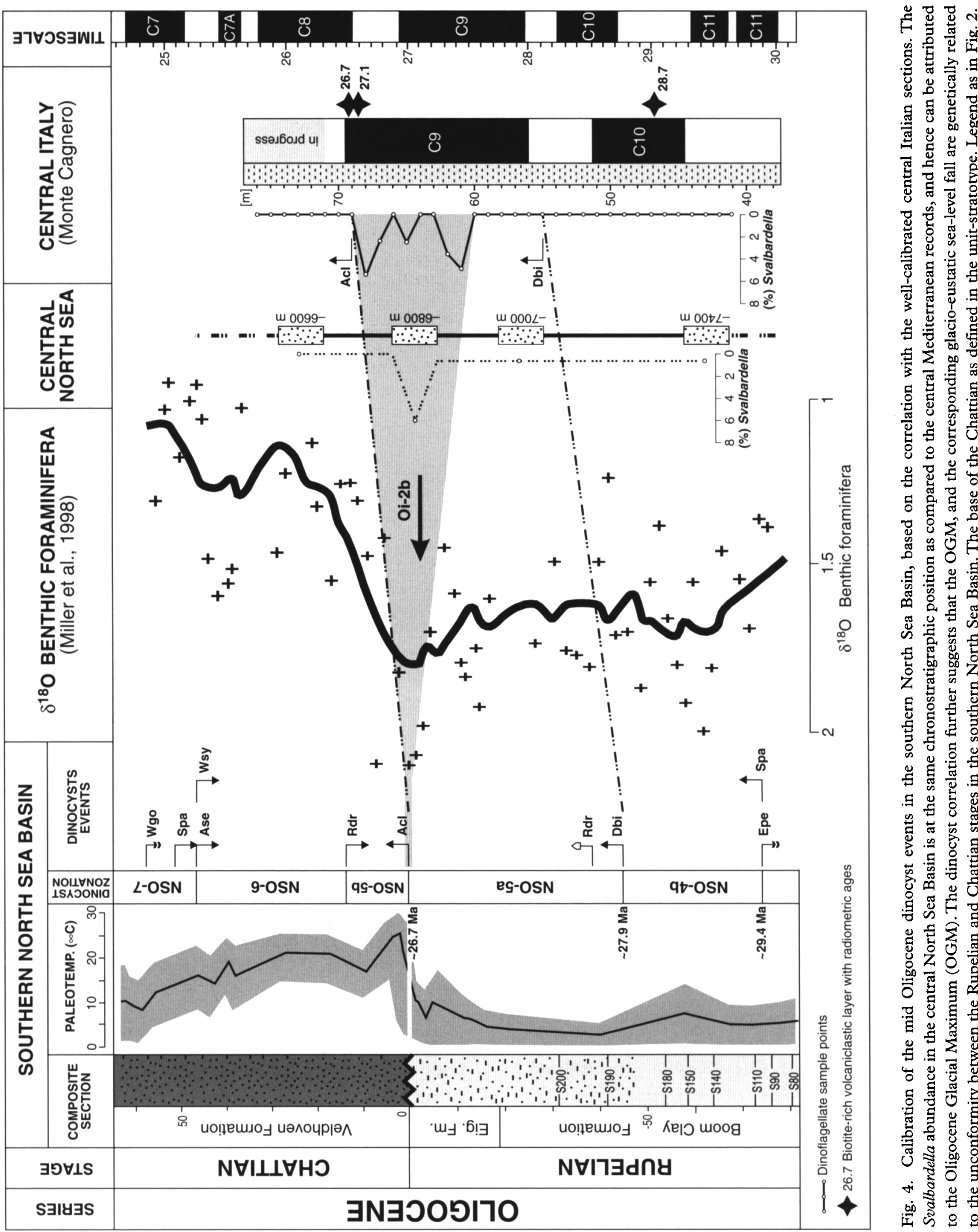
The dinocyst correlation thus suggests that the OGM, and the corresponding glacio-eustatic sea level fall are genetically related to the unconformity between the Rupelian and Chattian Stages in the southern North Sea Basin. The global sea level low during the latest Rupelian (magnetosubchron C9n) caused temporal sub-aerial exposure of the marginal marine southern North Sea Basin, triggering an erosional phase. The subsequent Late Oligocene Warming Event, calibrated against magnetochron $\mathrm{C} 8$, induced a major sea level rise, which transgressed over the marginal marine southern North Sea Basin. The erosive nature of the Chattian transgression is witnessed by the isolated, reworked specimens of Svalbardella spp. at the base of the Chattian in the southern North Sea Basin.

The duration of the gradual, pervasive sea level rise between the OGM sea level low $(-26.8 \mathrm{Ma})$ and the LOWE maximum sea level high $(\sim 26 \mathrm{Ma})$ lasted approximately $\sim 0.8 \mathrm{Ma}$. The oldest of the time-transgressive glauconitic fine Chattian sands in the southern North Sea Basin were deposited around 26.7 Ma.

An important consequence of these results is that any R-C GSSP should be positioned to match at least the age of the basal Chattian deposits, here correlated to magnetosubchron C8r. In addition, it should be positioned above the middle part of magnetosubchron C9n, i.e. above the Rupelian s.s. It has become clear that this phase in Earth history is intrinsically related to a global cold transient event, the OGM. It may be argued that the positioning of the R-C GSSP should involve multiple criteria, including peak Arctic dinoflagellate migration, heavy planktonic and benthic $\delta^{18} \mathrm{O}$ values, and peak sea level fall.

\section{Acknowledgements}

The author would like to express his gratitude to Henk Brinkhuis for lively discussions and constructive comments on the manuscript. Special thanks are due to Claus Heilmann-Clausen for access to the Mona borehole slides and sharing unpublished Oligocene data. Both F. Gradstein and E. Molina reviewed a first draft of this paper and gave fruitful comments. The author acknowledges support from the University of Leuven (Special Faculty Section nr. 12692 Grant).

\section{References}

Berggren, W.A., Kent, D.V., Swisher, III, C.C. \& Aubry, M.-P., 1995. A revised Cenozoic geochronology and chronostratigraphy. In: Berggren, W.A., Kent, D.V., Aubry, M.-P. \& Hardenbol, J. (eds): Geochronology, time scales and global stratigraphic correlation. Special Publication 54. Society of Economic Paleontologists and Mineralogists (Tulsa): 129-212.
Brinkhuis, H., 1994. Late Eocene to Early Oligocene dinoflagellate cysts from the Priabonian type-area (Northeast Italy): biostratigraphy and paleoenvironmental interpretation. Palaeogeography, Palaeoclimatology, Palaeoecology 107: 121-163.

Brinkhuis, H., Powell, A.J. \& Zevenboom, D., 1992. High-resolution dinoflagellate cyst stratigraphy of the Oligocene/Miocene transition interval in northwest and central Italy. In: Head, M.J. \&Wrenn, J.H. (eds): Neogene and Quaternary dinoflagelate cysts and acritarchs. American Association Stratigraphic Palynologists: 219-258.

Brinkhuis, H. \& Biffi, U., 1993. Dinoflagellate cyst stratigraphy of the Eocene/Oligocene transition in central Italy. Marine Micropaleontology 22: 131-183.

Brinkhuis, H. \& Visscher, H., 1995. The upper boundary of the Eocene series: a reappraisal based on dinoflagellate cyst biostratigraphy and sequence stratigraphy. In: Berggren, W.A., Kent, D.V., Aubry, M.-P. \& Hardenbol, J. (eds): Geochronology, time scales and global stratigraphic correlation. Special Publication 54. Society of Economic Paleontologists and Mineralogists (Tulsa): 295-304.

Brinkhuis, H., Munsterman, D.K., Sengers, S., Sluijs, A., Warnaar, J. \& Williams, G.L., 2003. Late Eocene-Quaternary dinoflagellate cysts from ODP Site 1168, off western Tasmania. In: Exon, N.F., Kennett, J.P. \& Malone, M.J., (eds): Proceedings of the Ocean Drilling Program, Scientific Results 189: 1-36 [Online]. Available from World Wide Web: <http:/www-odp.tamu.edu/ publications/189_SR/VOLUME/CHAPTERS/105.PDF>.

Coccioni, R., Bellanca, A., Bice, D.M., Brinkhuis, H., Church, N., Deino, A, Lirer, F, Macalady, A., Maiorano, P., Mancin, N., McDaniel, A., Monechi, S., Montanari, A., Neri, R., Nini, C., Nocchi, M., Pross, J., Rochette, P., Sagnotti, L., Sprovieri, M., Tateo, F., Touchard, Y., Van Simaeys, S. \& Williams, G.L., (submitted). Integrated stratigraphy of the Oligocene pelagic sequence in the Umbria-Marche Basin (Northeastern Apennines, Italy): A protential GSSP for the Rupelian/Chattian boundary. Geological Society of America, Bulletin.

De Man, E. \& Van Simaeys, S., 2004. Late Oligocene Warming Event in the southern North Sea Basin: benthic foraminifera as paleotemperature proxies. Netherlands Journal of Geosciences / Geologie en Mijnbouw 83(3): 227-239.

De Man, E., Van Simaeys, S., De Meuter, F., King, C. \& Steurbaut, E., 2004. Oligocene benthic foraminiferal zonation for the southern North Sea Basin. Bulletin van het Koninklijk Belgisch Instituut voor Natuurwetenschappen - Aardwetenschappen, 74 supplement: 177-195.

Doppert, J.W.C. \& Neele, N.G., 1983. Biostratigraphy of marine Paleogene deposits in the Netherlands and adjacent areas. Mededelingen Rijks Geologische Dienst 37(2): 4-79.

Eldrett, J.S., Harding, I.C., Firth, J.V. \& Roberts, A.P., 2004. Magnetostratigraphic calibration of Eocene-Oligocene dinoflagellate cyst biostratigraphy from the Norwegian-Greenland Sea. Marine Geology 204: 91-127.

Ellermann, C., 1958. Die mikrofaunistische Gliederung des Oligozäns im Schacht Kapellen bei Moers (Niederrhein). Fortschritte Geologie von Rheinland und Westfalen 1: 205-214.

Indans, J., 1958. Mikrofaunistische Korrelationen im marinen Tertiär der Niederrheinischen Bucht. Fortschritte Geologie für Rheinland und Westfalen 1: 223-238.

Indans, J., 1965. Nachweis des Asterigerinen-Horizontes im Oberoligozän des Dobergs bei Bünde/Westfalen. Neues Jahrbuch Geologie und Paläontologie, Abhandlungen 123(1): 20-24. 
King, C., 1983. Cainozoic micropalaeontological biostratigraphy of the North Sea. Report Institute of Geological Sciences 82(7): $1-40$.

King, C., 1989. Cenozoic of the North Sea. In: Jenkins, D.G. \& Murray, J.W. (eds): Stratigraphical atlas of fossil foraminifera. British Micropalaeontological Society Series. Ellis Horwood Limited (Chichester): 418-489.

Miller, K.G., Wright, J.D. \& Fairbanks, R.G., 1991. Unlocking the ice house: Oligocene-Miocene oxygen isotopes, eustacy, and margin erosion. Journal Geophysical Research 96: 6829-6848.

Miller, K.G., Mountain, G.S., Browning, J.V., Kominz, M., Sugerman, P.J., Christie-Blick, N., Katz, M.E. \& Wright, J.D., 1998. Cenozoic global sea level, sequences, and the New Jersey transect: results from coastal plain and continental slope drilling. Reviews of Geophysics 36(4): 569-601.

Odin, G.S. \& Montanari, A., 1988. The Eocene-Oligocene boundary at Massignano (Ancona, Italy): a potential boundary stratotype. In: Premoli Silva, I., Coccioni, R. \& Montanari, A. (eds): The Eocene-Oligocene Boundary in the Marche-Umbria Basin (Italy). International Union of Geological Sciences Commission on Stratigraphy, International Subcommission on Paleogene Stratigraphy Reports (Ancona, Italy): 253-263.

Odin, G.S. \& Montanari, A., 1989. Age radiométrique et stratotype de la limite Eocène-Oligocene. Comptes Rendus de l'Académie des Sciences 309 (serie II): 1939-1945.

Salvador, A., 1994. International stratigraphic guide. The international Union of Geological Sciences and The Geological Society of America, (Boulder, Colorado): $214 \mathrm{pp}$.

Scotese, C.P. \& Golanka, J., 1992. Paleogeographic atlas, PALEOMAP progress report 20-0692. Arlington, University of Texas: $34 \mathrm{pp}$.

Sissingh, W., 2003. Tertiary paleogeographic and tectonostratigraphic evolution of the Rhenish Triple Junction. Palaeogeography, Palaeoclimatology, Palaeoecology 196: 229-263.

Steininger, F.F., Aubry, M.-P., Berggren, W.A., Biolzi, M., Borsetti, A.M., Cartlidge, J.E., Cati, F., Corfield, R., Gelati, R., Iaccarino, S., Napoleone, C., Ottner, F., Rogl, F., Roetzel, R., Spezzaferri, S., Tateo, F., Villa, G. \& Zevenboom, D., 1997. The Global Stratotype Section and Point (GSSP) for the base of the Neogene. Episodes 20(1): 23-28.

Ulleberg, K., 1987. Foraminiferal zonation of the Danish Oligocene sediments. Bulletin Geological Society Denmark 36: 191-202.

Vandenberghe, N., Laga, P., Steurbaut, E., Hardenbol, J. \& Vail, P., 1998. Tertiary sequence stratigraphy at the southern border of the North Sea basin in Belgium. In: De Graciansky, P., Hardenbol, J., Jacquin, T. \& Vail, P. (eds): Mesozoic and Cenozoic Sequence Stratigraphy of European Basins. SEPM Special Publication 60: 119-154.
Vandenberghe, N., Hager, H., Van Den Bosch, M., Verstraelen, A., Leroi, S., Steurbaut, E., Prüfert, J. \& Laga, P., 2001. Stratigraphic correlation by calibrated well logs in the Rupel Group between North Belgium, the Lower-Rhine area in Germany and Southern Limburg and the Achterhoek in The Netherlands. In: Vandenberghe, N. (ed): Contributions to the Paleogene and Neogene Stratigraphy of the North Sea Basin. Aardkundige Mededelingen 11. Leuven University Press (Leuven): 69-84.

Van Simaeys, S., De Man, E., Vandenberghe, N., Brinkhuis, H. \& Steurbaut, E., 2004. Stratigraphic and palaeoenvironmental analysis of the Rupelian-Chattian transition in the type region: evidence from dinoflagellate cysts, foraminifera and calcareous nannofossils. Palaeogeography, Palaeoclimatology, Palaeoecology 208: 31-58.

Van Simaeys, S., Munsterman, D. \& Brinkhuis, H., (in press). Oligocene dinoflagellate cyst biostratigraphy of the southern North Sea Basin. Review Paleobotany and Palynology.

Van Simaeys, S., Brinkhuis, H., Pross, J., Williams, G. \& Zachos, J., (submitted). Arctic dinoflagellate migration marks the Oligocene Glacial Maximum. Geology.

Van Simaeys, S., Pross, J., Williams, G. \& Brinkhuis, H., (in prep.). Oligocene dinoflagellate cyst biochronostratigraphy: Implications towards the Rupelian-Chattian boundary.

Williams, G.L., Brinkhuis, H., Pearce, M.A, Fensome, R.A. \& Weegink, J.W., 2004. Southern Ocean and global dinoflagellate cyst events compared; Index events for the Late CretaceousNeogene. In: Exon, N.F., Kennett, J.P. \& Malone, M.J. (eds): Proceedings of the Ocean Drilling Program, Scientific Results ODP Leg 189: 1-98 [Online]. Available from World Wide Web: $<$ http://www.odp.tamu.edu/publications/189_SR/VOLUME/ CHAPTERS/107. PDF $>$.

Wilpshaar, M., Santarelli, A., Brinkhuis, H. \& Visscher, H., 1996. Dinoflagellate cysts and mid-Oligocene chronostratigraphy in the central Mediterranean region. Journal of the Geological Society of London 153: 553-561.

Zachos, J.C., Pagani, M., Sloan, L., Thomas, E. \& Billups, K., 2001. Trends, rhythms, and aberrations in global climate $65 \mathrm{Ma}$ to present. Science 292: 686-693.

Zevenboom, D., 1995. Dinoflagellate cysts from the Mediterranean Late Oligocene and Miocene. PhD Thesis, University Utrecht: $221 \mathrm{pp}$.

Ziegler, P.A., 1990. Geological atlas of western and central Europe. Shell Internationale Petroleum Maatschappij B.V. (Den Haag): $239 \mathrm{pp}$. 